\title{
Organogenesis of Tomato (Lycopersicon esculentum Mill.) cv. Sandra and Rocky by Hypocotyl, Cotyledon and Leaf Explants
} By

\section{Gharbia Hormiz Danial - Diaa Ayoub Ibrahim}

Scientific Research Center (SRC), College of Science, University of Duhok, Duhok, IRAQ
Doi: 10.21608/asajs.2020.67988

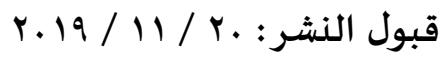

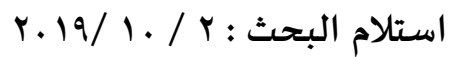

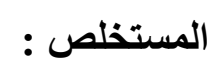

1(Lycopersicon esculentum تكوين اعضاء صنفين من نبات الطماطة

و Mill.) cv. Sandra and Rocky وقطع الاوراق بتقنية الزراعة النسيجيتمت نداخلات لتمايز صنفين من نبات الاته

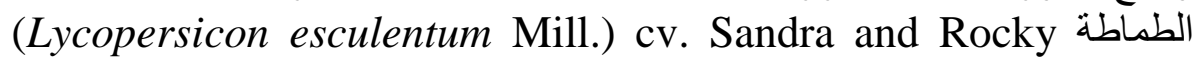
باستعمال الاوراق الفلقية والسيقات تحت الفلقية فضلا عن قطع الاور اق. اخذت القت القطع

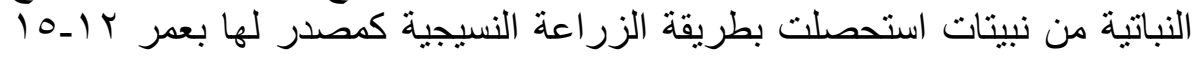

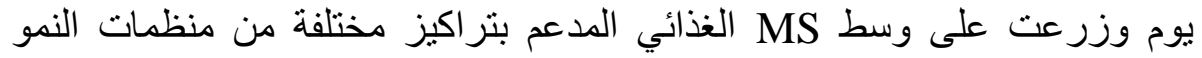

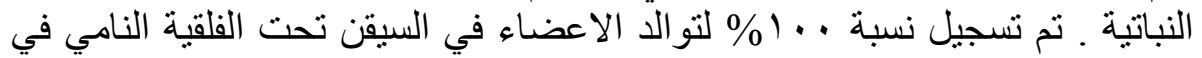

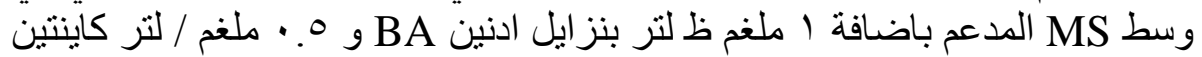

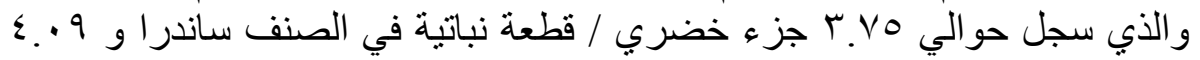

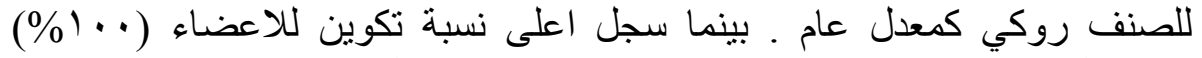

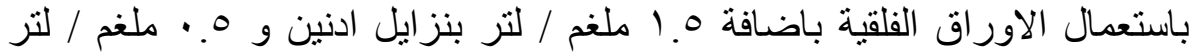

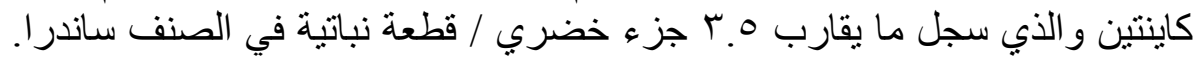

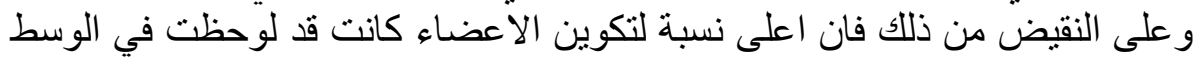

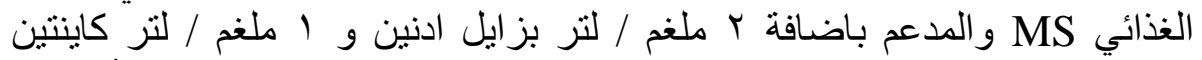

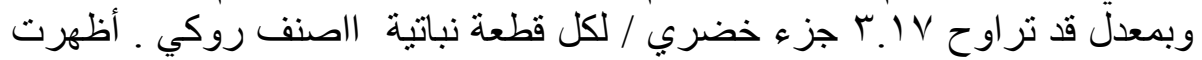

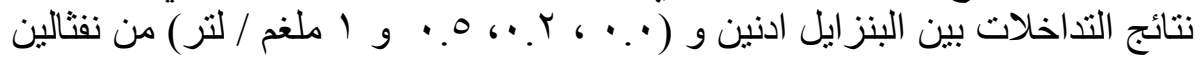

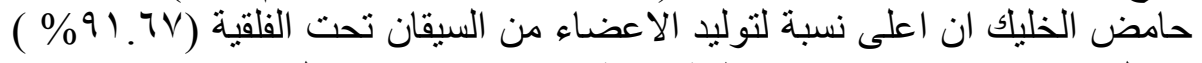

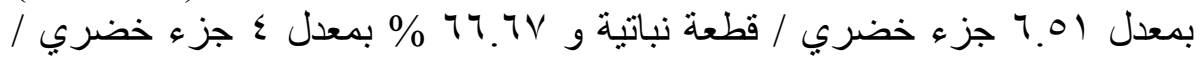
قطعة نباتية في الصنف ساندر او روكي على التو الي و النامية في وسط نو 


\section{Gharbia Danial - Diaa Ibrahim}

Doi: 10.21608/asajs.2020.67988

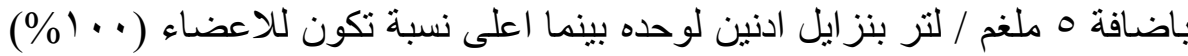

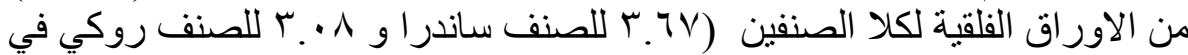

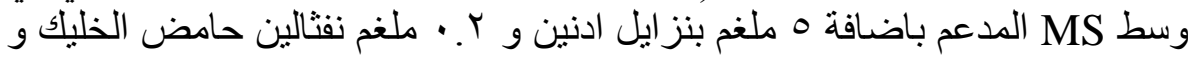

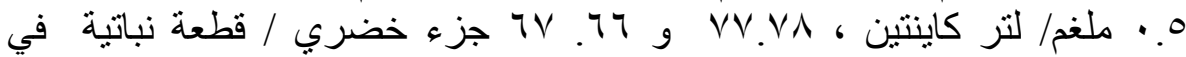

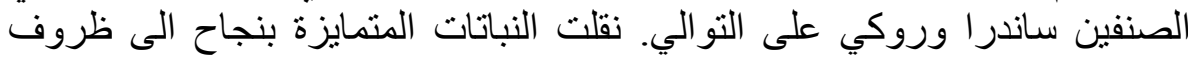

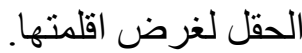

\section{Abstract:}

In vitro regeneration protocols were established for two Tomato (Lycopersicon esculentum Mill.) cultivars (Sandra and Rocky) grown in Kurdistan region using hypocotyl, cotyledonous leaves and leaf explants. The explants excised from 12-15 days old of in vitro plantlets cultured on MS medium supplemented with different concentrations and combinations of plant growth regulators. High organogenesis percentage (100\%) was achieved from hypocotyl grown in MS medium augmented with $1.0 \mathrm{mgl}^{-1} \mathrm{BA}+0.5 \mathrm{mgl}^{-1}$ kinetin, which record approximately 3.75 in Sandra and 4.09 in Rocky cultivar as average number of shoots produced from each explant. While the highest organogenesis percentage $(100 \%)$ was formed from cotyledon leaves using $1.5 \mathrm{mgl}^{-1} \mathrm{BA}+0.5 \mathrm{mgl}^{-1}$ kinetin that gave around 3.5 in Sandra cultivar as average number of shoots / explant. In contrast, the highest organogenesis was found on MS medium supplemented with $2.0 \mathrm{mgl}^{-1} \mathrm{BA}+1.0 \mathrm{mgl}^{-1}$ kinetin and the average number of shoots produced from each explant were approximately 3.17 in Rocky cultivar. The results of combination between $5.0 \mathrm{mgl}^{-1} \mathrm{BA}$ with $(0.0,0.2,0.5$ and 1.0) $\mathrm{mgl}^{-1}$ NAA, indicated that the highest organogenesis percentage was recorded from hypocotyl (91.67\% with 6.5 shoots/explant and $66.67 \%$ with 4.0 shoots/ explant) in Sandra and Rocky cultivars respectively grown on MS medium supplemented with $5.0 \mathrm{mgl}^{-1} \mathrm{BA}$ alone. While the highest organogenesis percentage $(100 \%)$ was induced from 
cotyledonous leaves in both cultivars (3.67 shoots for Sandra and 3.08 for Rocky) on MS medium supplemented with $5.0 \mathrm{mgl}^{-1}$ BA $+0.2 \mathrm{mgl}^{-1}$ NAA. Meanwhile, the highest organogenesis percentage was obtained from leaf explants for both cultivars on the combination of $1.0 \mathrm{mgl}^{-1} \mathrm{BA}+0.5 \mathrm{mgl}^{-1}$ kinetin, $(77.78 \%$ and $66.67 \%$ ) in Sandra and Rocky cultivars respectively. The regenerated plants were successfully transplanted to the field for acclimatization

Keywords Lycopersicon esculentum; Micropropagation; Organogenesis; TDZ, Kinetin.

\section{Introduction}

Tomato (Lycopersicon esculentum Mill.) is an important solanaceous crop, and is widely grown in the world. As a highly valuable and nutritious food, tomato is one of the major vegetables consumed by humans throughout the world. It is considered as the second most important vegetable crop after potato, being grown in tropical, sub-tropical and temperate areas (Mohamed et al., 2010). Tomato plays a vital role in maintaining human health and vigor. It has antioxidant properties and it is a source of vitamin $\mathrm{B}, \mathrm{C}$ and $\beta$-carotene, rich in fiber. Moreover, tomato is cholesterol free, hence, this feature gave it a medical significance to use for decrease the blood cholesterol, blood pressure, regulate blood sugar and boosts the immunity. Furthermore, consumption of tomatoes and its products decrease the risk of prostate cancer. As well as, it is a major component of vegetarian and non-vegetarian diets (Rao and Agarwal, 2000; Soundararajan, 2015).

In plant tissue culture, the organogenesis is the differentiation of unorganized mass of cells to development of adventitious organs. This system is commonly produced in callus 


\section{Gharbia Danial - Diaa Ibrahim}

Doi: 10.21608/asajs.2020.67988

culture, but it can be produced directly from the explants. It is regulated through a balance between the levels of auxins and cytokinins (Mohammed and Omar 1990). Tomato direct regeneration from hypocotyl and cotyledonous leaves has been previously reported via organogenesis in several researches using different levels of plant growth regulators (Abu-El-Heba et al., 2008; Mohamed et al., 2010; Wayase and Shitole 2014; Kalyani and Rao 2014; Soundararajan, 2015).

Many researches and reports showed a great deal of interesting to develop tomato crop by introducing value agronomic traits by either plant tissue culture or genetic transformation (Frary and Van Eck, 2005; Kole et al., 2010; Orozco-Cárdenas et al., 2014). Successful application of biotechnology in tomato improvement and tomato genetic transformation depends upon the type of explants and availability of efficient plant regeneration protocol, these factors could limits the plant genetic transformation (Evans, 1989). The current study will bring us closer to our goal of improving the tomato cultivars in Kurdistan Region of Iraq for both herbicide and abiotic stress resistance. However, there is no report on multiple shoots induction and direct regeneration from hypocotyls and cotyledon explants in tomato cv. ('Sandra' and 'Rocky') the two tomato genotypes that commonly grown in Kurdistan region of Iraq.

\section{Materials and Methods}

Seeds of tomato cultivars Sandra and Rocky were obtained from (Agriculture research station) Duhok Province, Kurdistan Region of Iraq in March, 2016. To remove dirt's and dusts, the seeds were thoroughly washed using running tap water, then the seeds were surface sterilized by immersing them in a mixture of $5 \%$ sodium hypochlorite $(\mathrm{NaOCl})$ solution with few drops of Tween-20 surfactant for 15 minutes. The seeds were removed 
and rinsed 3 times with autoclaved deionized water, blotted dry. Culture vessels containing MS (Murashige and Skoog, 1962) basal medium were used for culturing the sterilized seeds then were incubated in the dark for three days, transferred to growth room with a day photoperiod (16 hours light $/ 8$ hours dark at $25 \pm 2{ }^{\circ} \mathrm{C}$. Twelve to fifteen days after seed germination, hypocotyl, cotyledon and leaf explants were excised. Hypocotyl was sliced into $1-\mathrm{cm}$ explants and cotyledons were sliced into 1$\mathrm{cm}^{2}$. One group of those explants was cultured on MS sterilized medium supplemented with $\left(0.5,1.0 \mathrm{mgl}^{-1}\right)$ of Kinetin combined with $\left(0.5,1.0,1.5\right.$ and $\left.2.0 \mathrm{mgl}^{-1}\right)$ of BA. Other groups of explants were cultured on MS medium supplemented with $5.0 \mathrm{mgl}^{-1} \mathrm{BA}$ combined with $0.0,0.2,0.5$ and $1.0 \mathrm{mgl}^{-1} \mathrm{NAA}$, a total of 15 replicates were initiated for each treatment.

After six weeks of incubation, the organogenesis percentage, number of shoots and average shoots length were recorded.

\section{Data Analysis}

All the comparisons between means were carried out according to Duncan's multiple range test $(\mathrm{P}<0.05)$ using a computerized program of SAS.

\section{Results}

The key objective of this study is to obtain in vitro plants regeneration through organogenesis from hypocotyls, cotyledonous leaves and leaf sections. Hence, this technique can be used as a part of tomato genetic transformation protocol and then can transfer these new techniques into Kurdistan Region, as well as to encourage investment in this field of biotechnology for developing agriculture in Kurdistan.

During the present study, cotyledon, hypocotyl and leaf sections of two tomato genotypes (Sandra and Rocky) were 


\section{Gharbia Danial - Diaa Ibrahim}

Doi: 10.21608/asajs.2020.67988

excised and gained from in vitro grown seedlings (12-15 days old) as a source (Fig.1,A).

\section{Hypocotyl organogenesis}

Hypocotyl explants were cultured on MS medium supplemented with various combinations and concentrations of plant growth regulators. Two weeks after culture incubation, shoot induction was initiated. At the end of the 6 weeks of culture incubation, several shoots were initiated at the ends of the hypocotyl explants (Table1 and 2).

Table 1: Effect of different combinations between BA and Kinetin on direct organogenesis from hypocotyl explants of tomato (Lycopersicon esculentum Mill.) cv. Sandra and Rocky after six weeks of culture incubation.

\begin{tabular}{|c|c|c|c|c|}
\hline $\begin{array}{l}\text { Tomato } \\
\text { cultivars }\end{array}$ & $\begin{array}{l}\text { Growth } \\
\text { regulators }\end{array}$ & $\begin{array}{c}\text { Organogenesis } \\
\%\end{array}$ & $\begin{array}{l}\text { Shoots/ } \\
\text { explant } \\
\text { average }\end{array}$ & $\begin{array}{l}\text { Length } \\
\text { average } \\
(\mathrm{cm})\end{array}$ \\
\hline \multirow{5}{*}{ Sandra } & $\begin{array}{c}0.5 \mathrm{mgl}^{-1} \\
\mathrm{BA}+0.5 \\
\mathrm{mgl}^{-1} \text { Kinetin }\end{array}$ & 100 & $2.42 \mathrm{~b}$ & $0.39 \mathrm{~b}$ \\
\hline & $\begin{array}{c}\text { 1. } \mathrm{mgl}^{-1} \mathrm{BA}+ \\
0.5 \mathrm{mgl}^{-1} \\
\text { Kinetin }\end{array}$ & 100 & $3.75 \mathrm{a}$ & $0.54 \mathrm{~b}$ \\
\hline & $\begin{array}{c}1.5 \mathrm{mgl}^{-1} \\
\mathrm{BA}+0.5 \\
\mathrm{mgl}^{-1} \\
\text { Kinetin }\end{array}$ & 91.67 & $2.17 \mathrm{~b}$ & $0.54 \mathrm{~b}$ \\
\hline & $\begin{array}{l}2.0 \mathrm{mgl}^{-1} \\
\mathrm{BA}+1.0 \\
\mathrm{mgl}^{-1} \\
\text { Kinetin }\end{array}$ & 83.34 & $1.67 \mathrm{~b}$ & $0.43 \mathrm{~b}$ \\
\hline & $\begin{array}{l}0.5 \mathrm{mgl}^{-1} \\
\mathrm{BA}+0.5\end{array}$ & 100 & $3.09 \mathrm{a}$ & $1.13 \mathrm{a}$ \\
\hline
\end{tabular}




\begin{tabular}{|c|c|c|c|c|}
\hline \multirow[t]{4}{*}{ Rocky } & $\begin{array}{c}\mathrm{mgl}^{-1} \\
\text { Kinetin }\end{array}$ & & & \\
\hline & $\begin{array}{c}1.0 \mathrm{mgl}^{-1} \\
\mathrm{BA}+0.5 \\
\mathrm{mgl}^{-1} \\
\text { Kinetin }\end{array}$ & 100 & $4.09 \mathrm{a}$ & $1.15 \mathrm{a}$ \\
\hline & $\begin{array}{c}1.5 \mathrm{mgl}^{-1} \\
\mathrm{BA}+0.5 \\
\mathrm{mgl}^{-1} \\
\text { Kinetin }\end{array}$ & 66.67 & $1.59 \mathrm{~b}$ & $0.38 \mathrm{~b}$ \\
\hline & $\begin{array}{c}2.0 \mathrm{mgl}^{-1} \\
\mathrm{BA}+1.0 \\
\mathrm{mgl}^{-1} \\
\text { Kinetin }\end{array}$ & 91.67 & $3.42 \mathrm{a}$ & $0.35 \mathrm{~b}$ \\
\hline
\end{tabular}

Various letters in columns clarify significant differences at 5\% level according to Duncan test.

Table (1) showed that the highest organogenesis percentage $(100 \%)$ was found on MS medium augmented with 0.5 and $1.0 \mathrm{mgl}^{-1} \mathrm{BA}$ combined with $0.5 \mathrm{mgl}^{-1}$ kinetin for both cultivar Sandra (Fig.1,B) and Rocky (Fig.2,A), and the high average number of shoots produced from each explant was approximately 3.75 and 4 in Sandra and Rocky respectively. While lower organogenesis percentage (66.67\%) with lower shoots number 1.59 /explants was recorded in Rocky cultivar on MS medium content $1.5 \mathrm{mgl}^{-1} \mathrm{BA}$ combined with $0.5 \mathrm{mgl}^{-1}$ kinetin. On the other hand, high shoots length $1.15 \mathrm{~cm}$ was recorded in Rocky cultivar on MS medium supplemented with $1.0 \mathrm{mgl}^{-1} \mathrm{BA}+0.5 \mathrm{mgl}^{-1}$ kinetin that is significantly higher when compared with other growth regulator concentrations.

To study the effect of cytokinin with or without auxin combination on the organogenesis from hypocotyl explants, high concentration of BA $\left(5.0 \mathrm{mgl}^{-1}\right)+$ different concentrations of 


\section{Gharbia Danial - Diaa Ibrahim}

Doi: 10.21608/asajs.2020.67988

NAA $\left(0.0,0.2,0.5,1.0 \mathrm{mgl}^{-1}\right)$ were added to MS medium which was used for hypocotyl explants regeneration (Table 2).

Table 2: Effects of different combinations between $\mathrm{BA}$ and NAA on direct organogenesis from hypocotyl explants of tomato (Lycopersicon esculentum Mill.) cv. Sandra and Rocky after six weeks of culture incubation.

\begin{tabular}{|c|c|c|c|c|}
\hline $\begin{array}{l}\text { Tomato } \\
\text { cultivar }\end{array}$ & $\begin{array}{l}\text { Growth } \\
\text { regulators }\end{array}$ & $\begin{array}{c}\text { Organogenesis } \\
\%\end{array}$ & $\begin{array}{l}\text { Shoots/ } \\
\text { explant } \\
\text { average }\end{array}$ & $\begin{array}{l}\text { Length } \\
\text { average } \\
(\mathrm{cm})\end{array}$ \\
\hline \multirow{4}{*}{ Sandra } & $\begin{array}{c}5.0 \mathrm{mgl}^{-1} \\
\mathrm{BA}+0.0 \\
\mathrm{mgl}^{-1} \mathrm{NAA}\end{array}$ & $91.67 \mathrm{a}$ & $6.5 \mathrm{a}$ & $0.88 \mathrm{a}$ \\
\hline & $\begin{array}{c}5.0 \mathrm{mgl}^{-} \\
{ }^{1} \mathrm{BA}+0.2 \\
\mathrm{mgl}^{-1} \mathrm{NAA}\end{array}$ & $0 \mathrm{c}$ & $0 \mathrm{c}$ & $0 \mathrm{c}$ \\
\hline & $\begin{array}{c}5.0 \mathrm{mgl}^{-1} \\
\mathrm{BA}+0.5 \\
\mathrm{mgl}^{-1} \mathrm{NAA}\end{array}$ & $0 \mathrm{c}$ & $0 \mathrm{c}$ & $0 \mathrm{c}$ \\
\hline & $\begin{array}{c}5.0 \mathrm{mgl}^{-1} \\
\mathrm{BA}+1.0 \\
\mathrm{mgl}^{-1} \mathrm{NAA}\end{array}$ & $0 \mathrm{c}$ & $0 \mathrm{c}$ & $0 \mathrm{c}$ \\
\hline \multirow{4}{*}{ Rocky } & $\begin{array}{c}5.0 \mathrm{mgl}^{-1} \mathrm{BA}^{-} \\
0.0 \mathrm{mgl}^{-1} \\
\mathrm{NAA}\end{array}$ & $66.67 \mathrm{~b}$ & $4.0 \mathrm{~b}$ & $0.5 \mathrm{~b}$ \\
\hline & $\begin{array}{c}5.0 \mathrm{mgl}^{-} \\
{ }^{1} \mathrm{BA}+0.2 \\
\mathrm{mgl}^{-1} \mathrm{NAA}\end{array}$ & $8.33 \mathrm{c}$ & $0.25 \mathrm{c}$ & $0.25 \mathrm{~b}$ \\
\hline & $\begin{array}{c}5.0 \mathrm{mgl}^{-1} \\
\mathrm{BA}+0.5 \\
\mathrm{mgl}^{-1} \mathrm{NAA}\end{array}$ & $0 \mathrm{c}$ & $0 \mathrm{c}$ & $0 \mathrm{c}$ \\
\hline & $\begin{array}{c}5.0 \mathrm{mgl}^{-} \\
{ }^{1} \mathrm{BA}+1.0 \\
\mathrm{mgl}^{-1} \mathrm{NAA}\end{array}$ & $0 \mathrm{c}$ & $0 \mathrm{c}$ & $0 \mathrm{c}$ \\
\hline
\end{tabular}


Various letters in columns clarify significant differences at 5\% level according to Duncan test.

As showed in Table (2), the medium supplemented with $5 \mathrm{mgl}^{-1}$ BA without auxins was most effective in adventitious shoots induction for both Sandra and Rocky cultivars. The higher percentage of explants in Sandra cultivar that formed organogenesis was $91.67 \%$ followed by $66.67 \%$ in Rocky. This was significantly higher as compared with other treatments. The average number of shoots/explant were maximum (6.5) in Sandra cultivar (Fig.1, C) followed by 4.0 shoots/ explant in Rocky cultivar (Fig.2, B). While the higher length of shoots were $0.88 \mathrm{~cm}$ recorded in Sandra cultivar in the same medium.

\section{Cotyledons organogenesis}

The cotyledon explants that cultured on MS medium supplemented with different concentrations of BA combined with different levels of kinetin or NAA (Table 3 and 4) showed shoots regeneration which were developed after 2 weeks of incubation, and were well developed after the end of the 6 weeks.

Table 3: Effects of BA and Kinetin combinations on direct organogenesis from Cotyledon leaf explants of tomato (Lycopersicon esculentum Mill.) cv. Sandra and Rocky after six weeks of culture incubation.

\begin{tabular}{|c|c|c|c|c|}
\hline $\begin{array}{l}\text { Tomato } \\
\text { cultivar }\end{array}$ & $\begin{array}{l}\text { Growth } \\
\text { regulators }\end{array}$ & $\begin{array}{c}\text { Organogenesis } \\
\%\end{array}$ & $\begin{array}{l}\text { Shoots/ } \\
\text { explant } \\
\text { average }\end{array}$ & $\begin{array}{c}\text { Length } \\
\text { average } \\
(\mathrm{cm})\end{array}$ \\
\hline & $\begin{array}{c}0.5 \mathrm{mgl}^{-1} \\
\mathrm{BA}+0.5 \\
\mathrm{mgl}^{-1} \\
\text { Kinetin }\end{array}$ & 50 & $3.25 \mathrm{~b}$ & $0.69 a b$ \\
\hline Sandra & $\begin{array}{c}1.0 \mathrm{mgl}^{-1} \\
\mathrm{BA}+0.5 \\
\mathrm{mgl}^{-1}\end{array}$ & 83.34 & $3.71 \mathrm{~b}$ & $1.00 \mathrm{a}$ \\
\hline
\end{tabular}


Doi: 10.21608/asajs.2020.67988

\begin{tabular}{|c|c|c|c|c|}
\hline & Kinetin & & & \\
\hline & $\begin{array}{c}1.5 \mathrm{mgl}^{-1} \\
\mathrm{BA}+0.5 \\
\mathrm{mgl}^{-1} \\
\text { Kinetin }\end{array}$ & 100 & $3.50 \mathrm{~b}$ & $0.93 \mathrm{a}$ \\
\hline & $\begin{array}{c}2.0 \mathrm{mgl}^{-1} \\
\mathrm{BA}+1.0 \\
\mathrm{mgl}^{-1} \\
\text { Kinetin }\end{array}$ & 100 & $3.25 \mathrm{~b}$ & $0.49 \mathrm{~b}$ \\
\hline \multirow{4}{*}{ Rocky } & $\begin{array}{c}0.5 \mathrm{mgl}^{-1} \\
\mathrm{BA}+0.5 \\
\mathrm{mgl}^{-1} \\
\text { Kinetin }\end{array}$ & 75 & $2.88 \mathrm{~b}$ & $0.77 \mathrm{ab}$ \\
\hline & $\begin{array}{c}1.0 \mathrm{mgl}^{-1} \\
\mathrm{BA}+0.5 \\
\mathrm{mgl}^{-1} \\
\text { Kinetin }\end{array}$ & 100 & $2.84 \mathrm{~b}$ & $0.50 \mathrm{~b}$ \\
\hline & $\begin{array}{c}1.5 \mathrm{mgl}^{-1} \\
\mathrm{BA}+0.5 \\
\mathrm{mgl}^{-1} \\
\text { Kinetin }\end{array}$ & 58.33 & $4.58 \mathrm{a}$ & $0.57 \mathrm{~b}$ \\
\hline & $\begin{array}{c}2.0 \mathrm{mgl}^{-1} \\
\mathrm{BA}+1.0 \\
\mathrm{mgl}^{-1} \\
\text { Kinetin }\end{array}$ & 100 & $3.17 \mathrm{~b}$ & $0.49 \mathrm{~b}$ \\
\hline
\end{tabular}

Various letters in columns clarify significant differences at 5\% level according to Duncan test.

In Sandra cultivar, the highest organogenesis percentage $(100 \%)$ was achieved on the combination of $1.5 \mathrm{mgl}^{-1}$ $\mathrm{BA}+0.5 \mathrm{mgl}^{-1}$ Kinetin and $2.0 \mathrm{mgl}^{-1} \mathrm{BA}+1.0 \mathrm{mgl}^{-1}$ Kinetin (Fig.1, D). Meanwhile, the lower organogenesis percentage (50\%) was recorded in the combination of $0.5 \mathrm{mgl}^{-1}$ for each of BA and kinetin. While in Rocky cultivar, the highest organogenesis 
percentage $(100 \%)$ was recorded on MS medium containing either $\left(1.0 \mathrm{mgl}^{-1} \mathrm{BA}+0.5 \mathrm{mgl}^{-1}\right.$ kinetin) or $\left(2.0 \mathrm{mgl}^{-1} \mathrm{BA}+1.0 \mathrm{mgl}^{-1}\right.$ kinetin). Whereas the least organogenesis percentage (58.33\%) was observed on MS medium supplemented with $\left(1.5 \mathrm{mgl}^{-1} \mathrm{BA}+\right.$ $0.5 \mathrm{mgl}^{-1}$ kinetin), and the maximum number of shoots 4.58 /explants was recorded in this medium for cv. Rocky (Fig.2, C), this increment was significant when compared to all other treatments. The length of shoot reached to $1.0 \mathrm{~cm}$ on MS medium supplemented with $\left(1.0 \mathrm{mgl}^{-1} \mathrm{BA}+0.5 \mathrm{mgl}^{-1}\right.$ kinetin) which is significantly high. In contrast, the length of shoot was reduced drastically with increased BA and kinetin concentration, and the least shoot length $0.49 \mathrm{~cm}$ attained it on MS medium containing $2.0 \mathrm{mgl}^{-1} \mathrm{BA}+1.0 \mathrm{mgl}^{-1}$ kinetin for both cultivars.

The organogenesis responses from the cotyledon leaf explants on MS medium containing $5.0 \mathrm{mgl}^{-1} \mathrm{BA}$ combined with different concentrations of NAA is shown in Table 4.

Table 4: Effect of different combinations between BA and NAA on direct organogenesis from Cotyledon leaf explants of tomato (Lycopersicon esculentum Mill.) cv. Sandra and Rocky after six weeks of incubation.

\begin{tabular}{|c|c|c|c|c|}
\hline $\begin{array}{c}\text { Tomato } \\
\text { cultivar }\end{array}$ & $\begin{array}{c}\text { Growth } \\
\text { regulators }\end{array}$ & $\begin{array}{c}\text { Organogenesis } \\
\%\end{array}$ & $\begin{array}{c}\text { Shoots/ } \\
\text { explant } \\
\text { average }\end{array}$ & $\begin{array}{c}\text { Length } \\
\text { average } \\
(\mathrm{cm})\end{array}$ \\
\hline \multirow{5}{*}{ Sandra } & $\begin{array}{c}5.0 \mathrm{mgl}^{-1} \\
\mathrm{BA}+0.0 \\
\mathrm{mgl}^{-1} \mathrm{NAA}\end{array}$ & 33.33 & $1.38 \mathrm{~b}$ & $0.25 \mathrm{a}$ \\
\cline { 2 - 5 } & $\begin{array}{c}5.0 \mathrm{mgl}^{-1} \\
\mathrm{BA}+0.2 \\
\mathrm{mgl}^{-1} \mathrm{NAA}\end{array}$ & 100 & $3.67 \mathrm{a}$ & $0.29 \mathrm{a}$ \\
\cline { 2 - 5 } & $\begin{array}{c}5.0 \mathrm{mgl}^{-1} \\
\mathrm{BA}+0.5 \\
\mathrm{mgl}^{-1} \mathrm{NAA}\end{array}$ & 0 & $0 \mathrm{e}$ & $0 \mathrm{c}$ \\
\cline { 2 - 6 } & $5.0 \mathrm{mgl}^{-1}$ & 16.67 & $0.25 \mathrm{c}$ & $0.08 \mathrm{c}$ \\
\hline
\end{tabular}




\section{Gharbia Danial - Diaa Ibrahim}

Doi: 10.21608/asajs.2020.67988

\begin{tabular}{|c|c|c|c|c|}
\hline & $\begin{array}{c}\mathrm{BA}+1.0 \\
\mathrm{mgl}^{-1} \mathrm{NAA}\end{array}$ & & & \\
\hline \multirow{4}{*}{ Rocky } & $\begin{array}{c}5.0 \mathrm{mgl}^{-1} \\
\mathrm{BA}+0.0 \\
\mathrm{mgl}^{-1} \mathrm{NAA}\end{array}$ & 16.67 & $1.0 \mathrm{~d}$ & $0.15 \mathrm{~b}$ \\
\hline & $\begin{array}{c}5.0 \mathrm{mgl}^{-1} \\
\mathrm{BA}+0.2 \\
\mathrm{mgl}^{-1} \mathrm{NAA}\end{array}$ & 100 & $3.08 \mathrm{a}$ & $0.34 \mathrm{a}$ \\
\hline & $\begin{array}{c}5.0 \mathrm{mgl}^{-1} \\
\mathrm{BA}+0.5 \\
\mathrm{mgl}^{-1} \mathrm{NAA}\end{array}$ & 25 & $0.5 \mathrm{c}$ & $0.13 \mathrm{~b}$ \\
\hline & $\begin{array}{c}5.0 \mathrm{mgl}^{-1} \\
\mathrm{BA}+1.0 \\
\mathrm{mgl}^{-1} \mathrm{NAA}\end{array}$ & 0 & $0 \mathrm{e}$ & $0 \mathrm{c}$ \\
\hline
\end{tabular}

Various letters in columns clarify significant differences at 5\% level according to Duncan test.

The highest and best shoots induction (100\%) of organogenesis percentage was noticed on MS medium containing $5.0 \mathrm{mgl}^{-1}$ BA combined with $0.2 \mathrm{mgl}^{-1}$ NAA. Furthermore, the highest mean number of shoots regenerated (3.67 and 3.08 shoots/explant) with high average of length 0.29 and $0.34 \mathrm{~cm}$ were observed in Sandra and Rocky respectively on the same medium, that was significantly higher when compared with other treatments (Fig. 1, E) and (Fig.2, D). While the medium containing high concentration of NAA $\left(0.5\right.$ and $1.0 \mathrm{mgl}^{-}$ ${ }^{1}$ ) shows very low or no response for organogenesis in both cultivars.

\section{Leaves organogenesis}

Concerning the organogenesis from tomato leaf explants, BA combinations with either NAA or kinetin were investigated at different concentrations. Table (5) showed the organogenesis percent of the cultured explants on MS medium supplemented with different concentrations of growth regulators. 
Table 5: Effect of different combinations between BA and NAA, BA and Kinetin on direct organogenesis from leaf explants of tomato (Lycopersicon esculentum Mill.) cv. Sandra and Rocky after six weeks of incubation.

\begin{tabular}{|c|c|c|c|c|}
\hline $\begin{array}{l}\text { Tomato } \\
\text { cultivar }\end{array}$ & $\begin{array}{l}\text { Growth } \\
\text { regulators }\end{array}$ & $\begin{array}{c}\text { Organogenesis } \\
\%\end{array}$ & $\begin{array}{l}\text { Shoots/ } \\
\text { explant } \\
\text { average }\end{array}$ & $\begin{array}{l}\text { Length } \\
\text { average } \\
(\mathrm{cm})\end{array}$ \\
\hline \multirow{4}{*}{ Sandra } & $\begin{array}{c}5.0 \mathrm{mgl}^{-1} \\
\mathrm{BA}+0.0 \\
\mathrm{mgl}^{-1} \mathrm{NAA}\end{array}$ & 55.56 & $1.83 \mathrm{c}$ & $0.30 \mathrm{~b}$ \\
\hline & $\begin{array}{c}5.0 \mathrm{mgl}^{-1} \\
\mathrm{BA}+0.2 \\
\mathrm{mgl}^{-1} \mathrm{NAA}\end{array}$ & 22.22 & $1.67 \mathrm{c}$ & $0.10 \mathrm{c}$ \\
\hline & $\begin{array}{c}0.5 \mathrm{mgl}^{-1} \\
\mathrm{BA}+0.5 \mathrm{~m} \\
\mathrm{mgl}^{-1} \\
\text { Kinetin }\end{array}$ & 66.67 & $1.83 \mathrm{c}$ & $0.47 \mathrm{~b}$ \\
\hline & $\begin{array}{c}1.0 \mathrm{mgl}^{-1} \\
\mathrm{BA}+0.5 \\
\mathrm{mgl}^{-1} \\
\text { Kinetin }\end{array}$ & 77.78 & $2.22 b c$ & $0.24 \mathrm{~b}$ \\
\hline \multirow{4}{*}{ Rocky } & $\begin{array}{c}5.0 \mathrm{mgl}^{-1} \\
\mathrm{BA}+0.0 \\
\mathrm{mgl}^{-1} \mathrm{NAA}\end{array}$ & 44.44 & $3.83 \mathrm{a}$ & $0.18 \mathrm{~b}$ \\
\hline & $\begin{array}{c}5.0 \mathrm{mgl}^{-1} \\
\mathrm{BA}+0.2 \\
\mathrm{mgl}^{-1} \mathrm{NAA}\end{array}$ & 0.0 & $0.0 \mathrm{~d}$ & $0.0 \mathrm{c}$ \\
\hline & $\begin{array}{c}0.5 \mathrm{mgl}^{-1} \\
\mathrm{BA}+0.5 \\
\mathrm{mgl}^{-1} \\
\text { Kinetin }\end{array}$ & 33.33 & $2.67 \mathrm{~b}$ & $0.63 \mathrm{a}$ \\
\hline & $\begin{array}{c}1.0 \mathrm{mg} / \mathrm{l} \\
\text { BA+0.5 mg/l } \\
\text { Kinetin }\end{array}$ & 66.67 & $2.67 \mathrm{~b}$ & $0.60 \mathrm{a}$ \\
\hline
\end{tabular}




\section{Gharbia Danial - Diaa Ibrahim}

Doi: 10.21608/asajs.2020.67988

Various letters in columns clarify significant differences at 5\% level according to Duncan test.

The highest organogenesis percentages (77.78 and $66.67 \%$ ) were achieved from both cultivars (Sandra and Rocky) respectively on the combination $\left(1.0 \mathrm{mgl}^{-1} \mathrm{BA}+0.5 \mathrm{mgl}^{-1}\right.$ kinetin) which were higher than the other treatments. Whereas, the least organogenesis percentage $(22.22 \%)$ was found on the medium augmented with $5.0 \mathrm{mgl}^{-1} \mathrm{BA}+0.2 \mathrm{mgl}^{-1} \mathrm{NAA}$ for Sandra cultivar, while in Rocky cultivar this medium did not show any response for organogenesis percentage.

The number of shoots/explant increased from 2.67 to 3.83 shoots/explant by changing the combination from media containing (1.0 $\mathrm{mgl}^{-1} \mathrm{BA}+0.5 \mathrm{mgl}^{-1}$ kinetin) to $\mathrm{MS}$ medium supplemented with $5.0 \mathrm{mgl}^{-1}$ BA in Rocky cultivar (Fig.2, E). This increase was highly significant when compared to all other treatments. Regarding Sandra cultivar, the highest number of shoots/explant 2.22 was recorded on MS medium supplemented with $1.0 \mathrm{mgl}^{-1} \mathrm{BA}$ combinations with $0.5 \mathrm{mgl}^{-1}$ kinetin.

The minimum shoot length was attained on MS medium supplemented with $5.0 \mathrm{mgl}^{-1} \mathrm{BA}$ combined with $0.2 \mathrm{mgl}^{-1} \mathrm{NAA}$, which reached to $0.10 \mathrm{~cm}$ as an average in Sandra cv., while the highest shoot length reached to $0.63 \mathrm{~cm}$ on $\mathrm{MS}$ medium supplemented with $0.5 \mathrm{mgl}^{-1} \mathrm{BA}+0.5 \mathrm{mgl}^{-1}$ kinetin in Rocky cultivar, that is significantly high when compared to all other treatments.

The regenerated shoots were rooted on MS medium and then transferred to pots containing soil in the greenhouse (Fig.1, F) and (Fig.2, F).

\section{Discussion}

The results in table 2 which related to the effect of the combination between BA and Kinetin are in agreement with previous findings that $\mathrm{BA}$ engorges direct shoot regeneration and 
the production of shoots per explant from hypocotyls of tomato when used in combination with kinetin (Rashid and Bal, 2010). Moreover, Hnur and Krishnareddy (2016) clearly indicated the role of kinetin with BAP into produce good embryogenic calli from hypocotyls explants in tomato and developed them to whole plantlets. Furthermore, many researchers have reported that kinetin and BA as important cytokinins with high shoot regeneration ability from hypocotyl explants when used in combination with some auxins such as NAA in the culture medium (Manawadu et al., 2014). Kauser et al. (2016) as well showed that the combination of $1.5 \mathrm{mgl}^{-1}$ BAP, $0.5 \mathrm{mgl}^{-1}$ zeatin and $0.2 \mathrm{mgl}^{-1}$ IAA was considered as the best medium for high plant regeneration rates from hypocotyl, cotyledon and leaf explants. These results can be explained that the effect of two types of cytokinins is more influence on direct shoot regeneration in tomato when compared with using one cytokinin (Kauser et al., 2016). However, other researchers found that the best regeneration medium for hypocotyls explants with high regeneration frequency $100 \%$ was MS medium supplemented with $1 \mathrm{mgl}^{-1}$ zeatin and $0.1 \mathrm{mgl}^{-1}$ of indole 3- acetic acid (Gubis et al., 2004). Gubis et al. (2003) studied the regeneration ability of six types of explants in 13 cultivars of tomato and found that the most responsive explants were hypocotyles and epicotyls with up to $100 \%$ regeneration with average number of shoots range 6.3 and 6.5/explant respectively.

The findings in table 2 are in agreement with those published by Mohamed et al. (2010) who found that the MS medium supplemented with $2.0 \mathrm{mgl}^{-1} \mathrm{BAP}$ without any auxin induced high organogenesis percentage, high shoot number/ explant and high shoot length from hypocotyl explants of tomato. However, other studies have reported that MS medium supplemented with BAP and IAA was the best medium for shoot 


\section{Gharbia Danial - Diaa Ibrahim}

Doi: 10.21608/asajs.2020.67988

regeneration from hypocotyl explants of tomato (Wayase and Shitole 2014; Rashid et al., 2012). The reason behind the superiority of BAP alone on the BAP combined with NAA in shoot organogenesis from hypocotyl explants is due to the role of BAP in cell division and auxiliary bud formation (Sutter, 1996), as well as the ability to regeneration was substantially dependent on the type of explants (Gerszberg et al., 2016).

The results of table 3 are corresponded with other researches that demonstrate the role of cytokinin on In vitro organogenesis by using kinetin combination with BAP that hence callus induction and shoot regeneration from cotyledon leaves of tomato plant in absence of auxin (Rashid and Bal, 2010). In addition, Hnur and Krishnareddy (2016) also noted that the callus induction and plant regeneration from cotyledonous leaves of tomato plant was greatly influenced by addition of kinetin and BAP to MS medium. As well as, the reduction of organogenesis percentage from cotyledon leaf explants comparing with hypocotyl explants on the same medium may be due to the type of explant which used in the experiment.

Similar results of table 4 were obtained by Kalyani and Rao (2014) who found an efficient protocol for direct shoot regeneration from cotyledon explants of tomato, using MS medium supplemented with $1.0 \mathrm{mgl}^{-1}$ zeatin and $0.1 \mathrm{mgl}^{-1}$ IAA. Other studies have reported that the best explants for inducing shoot regeneration were cotyledon explants followed by hypocotyls of tomato on MS medium supplemented with $2.0 \mathrm{mgl}^{-}$ 1 BA and $0.1 \mathrm{mgl}^{-1}$ IAA (Gerszberg et al., 2016). Wayase and Shitole (2014) showed that the best medium for highest number of shoot induction from cotyledon explants (7.8 shoots / explant) were produce on MS medium containing 6.65 $\mu \mathrm{M}$ BAP combined with $1.14 \mu \mathrm{M}$ IAA. The reasons behind the positive role of the combination between the cytokinins and the auxins on 


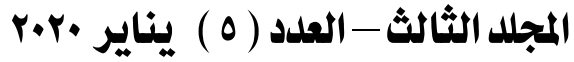

المجلة العربية للعلوم الزراعية

direct organogenesis in tomato might be due to the morphogenic response by modifying various physiological processes (Wayase and shitole, 2014).

The role of various concentrations of auxins and cytokinin in direct shoot regeneration or organogenesis of tomato was documented by Manawadu et al., (2014). As well as, Kauser et al., (2016) studied the effect of various combination between BAP, zeatin, IAA and IBA on direct shoot regeneration from leaf explants. While other studies found that the direct shoot regeneration obtained from leaf explants of cv. Moneymaker on a medium containing $1.0 \mathrm{mgl}^{-1}$ zeatin, $1.0 \mathrm{mg} / \mathrm{l} \mathrm{IAA}$ with B5 vitamins (Sarwarkhan et al., 2006). The reason of lower organogenesis percentage and shoots number from leaf explants comparing with cotyledon and hypocotyl explants in this study may be due to the type of explants as well as the type of plant growth regulators and concentration (Majoul et al., 2007). However, other research found that the better explants for direct

regeneration was the leaf bud when cultured on MS medium supplemented with $0.5 \mathrm{mgl}^{-1}$ kinetin $+2.0 \mathrm{mgl}^{-1} \mathrm{BAP}+0.1 \mathrm{mgl}^{-1}$ NAA (Manawadu et al., 2014).

\section{Figure 1: Direct organogenesis in tomato cv. Sandra}

A. The twelve days old seedling of in vitro grown tomato.

B. Shoots differentiation from hypocotyls explants on MS medium augmented with $1.0 \mathrm{mgl}^{-1} \mathrm{BA}+0.5 \mathrm{mgl}^{-1}$ kinetin after 6 weeks of culture.

C. Shoots differentiation from hypocotyl explants on MS medium augmented with $5.0 \mathrm{mgl}^{-1} \mathrm{BA}+1.0 \mathrm{mgl}^{-1} \mathrm{NAA}$ after 6 weeks of culture.

D. Shoots differentiation from cotyledon explants on MS medium augmented with $5.0 \mathrm{mgl}^{-1} \mathrm{BA}+0.2 \mathrm{mgl}^{-1}$ NAA after 6 weeks of culture. 


\section{Gharbia Danial - Diaa Ibrahim}

Doi: 10.21608/asajs.2020.67988

E. Shoots differentiation from cotyledon explants on MS medium augmented with $2.0 \mathrm{mgl}^{-1} \mathrm{BA}+1.0 \mathrm{mgl}^{-1}$ kinetin after 6 weeks of culture.
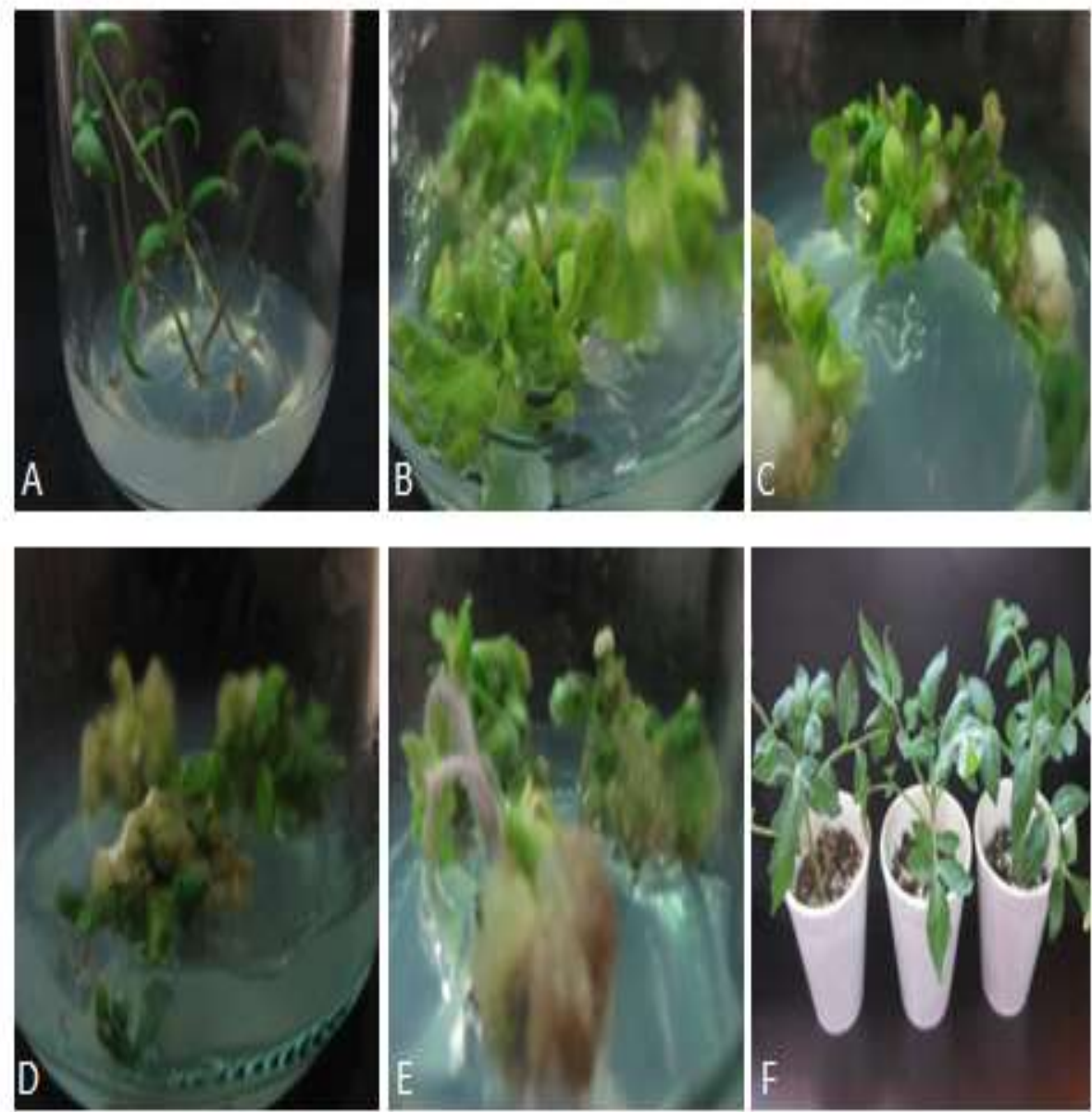

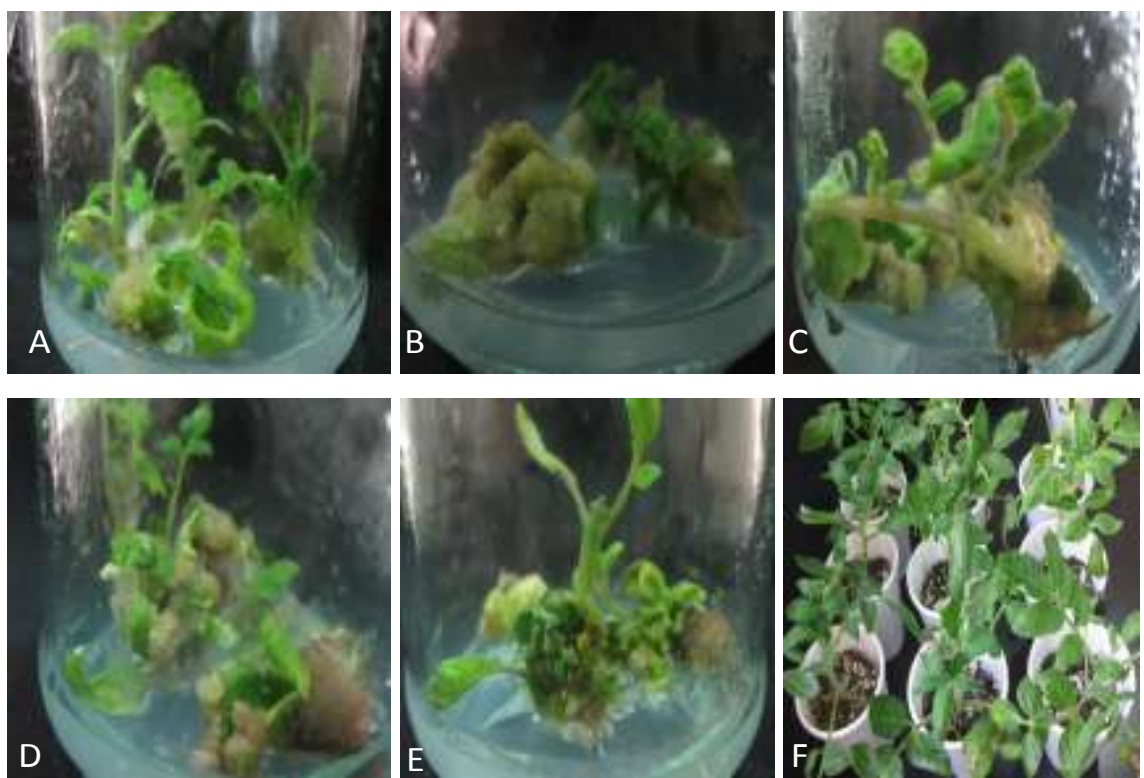

F. Plantlets transferred to the soil in the greenhouse.

Figure 2: Direct organogenesis in tomato cv. Rocky

A. Shoots differentiation from hypocotyls explants on MS medium augmented with $1.0 \mathrm{mgl}^{-1} \mathrm{BA}+0.5 \mathrm{mgl}^{-1}$ kinetin after 4 weeks of culture.

B. Shoots differentiation from hypocotyl explants on MS medium augmented with $1.0 \mathrm{mgl}^{-1} \mathrm{BA}+0.5 \mathrm{mgl}^{-1}$ kinetin after 6 weeks of culture.

C. Shoots differentiation from cotyledon explants on MS medium augmented with $5.0 \mathrm{mgl}^{-1} \mathrm{BA}+0.2 \mathrm{mgl}^{-1} \mathrm{NAA}$ after 4 weeks of culture.

D. Shoots differentiation from cotyledon explants on MS medium augmented with $5.0 \mathrm{mgl}^{-1} \mathrm{BA}+0.2 \mathrm{mgl}^{-1} \mathrm{NAA}$ after 6 weeks of culture. 


\section{Gharbia Danial - Diaa Ibrahim}

Doi: 10.21608/asajs.2020.67988

E. Shoots differentiation from leaf explants on MS medium augmented with $1.0 \mathrm{mgl}^{-1} \mathrm{BA}+0.5 \mathrm{mgl}^{-1}$ kinetin after 6 weeks of culture.

F. Plantlets transferred to the soil in the greenhouse.

\section{Conclusion}

In present study an efficient protocol for direct organogenesis from hypocotyls and cotyledon leaves in tomato plants through multiple shoot induction has been standardized, the regenerated plants were transferred to the soil successfully. The protocol established here can be serving as an efficient method for the rapid propagation and conservation of genetic transformations and many other biotechnological aspects for future studies. 


\section{References}

Abu-El- Heba, G. A.; Hussein, G. M. and Abdalla, N. A. 2008. $A$ rapid and efficient tomato regeneration and transformation system, Agriculture and Forestry Research, 58: $103-110$.

Evans, D. A. 1989. Somaclonal variation - genetic basis and breeding applications. Trends in Genetics 5(2): 46-50.

Frary, A. and Van Eck, J. 2005. Organogenesis from transformed tomato explants. Transgenic Plants: Methods and Protocols, pp.141-150.

Gerszberg, A.; Hnatuszko- Konka, K.; Kowalczyk, T. and Kononowicz,A.K. 2016. Efficient In vitro callus induction and plant regeneration protocol for different Polish tomato cultivars.Not. Bot. Horti. Agrobo.,44(2):452-458.

Gubis, J.; Lajchova, Z.; Farago, J. and Jurekova, Z. 2003. Effect of genotype and explant type on shoot regeneration in Tomato (Lycopersicom esculentum Mill.) in vitro. Czech J. Genet. Plant Breed 39(1):9-14.

Gubis, J.; Lajchova, Z.; Farago, J. and Jurekova, Z. 2004. Effect of growth regulators on shoot induction and plant regeneration in Tomato (Lycopersicom esculentum Mill.). Biologia Bratislava 59(3): 405-408.

Hanur, V. S. and Krishnareddy, B. 2016. In vitro organogenesis in Tomato (Solanum lycopersicum) using kinetin. Adv. Plants Agric. Res 4(6):00158.

Kalyani, B. G. and Rao, S. 2014. Zeatin induced direct plant regeneration from cotyledon explants of cultivated tomato (Lycopersicom esculentum Mill.). World Journal of Pharmacy and Pharmaceutical Sciences. ,3(7):1034-1040.

Kauser, N.; Khan, S.; Mohammadi, A.; Ghareyazil,B.; Uliaie, E. D. and Darvishrohani, B. 2016. Agrobactrium mediated transformation and direct shoot regeneration in Iranian 


\section{Gharbia Danial - Diaa Ibrahim}

Doi: 10.21608/asajs.2020.67988

Tomato (Solanum lycopersicum L.) cultivar Falat-CH.Pak. J. Bot., 48(6): 2489-2498.

Kole, C.; Michler, C.; Abbott, A. G.; Hall,T.C. 2010).

"Transgenic Crop Plants" Volume 1 Principles and

Development, Springer verlag Berline Heidelberg.

Majoul, H., R. ; Lengliz, S.; Gharsallah chouchane, F.; Gorsane,

H.; Fakhfakh and Marrakchi, M. 2007. Factors affecting tomato ( Lycopersicon esculentum Mill) transformation frequency. Acta Hort. (ISHS) 758:43-51.

Manawadu, I. ; Nilanthi, D. and Senanayake, S. 2014. Callus formation and organogenesis of Tomato (Lycopersicom esculentum Mill. Variety Thilina). Tropical Agriculture Research \& Extension 17(2):86-94.

Mohamed, A. A.; Ismail, M. R. and Rahman, M. H. 2010. In vitro response from cotyledon and hypocotyls explants in tomato by inducing 6- benzylaminopurine. African Journal of Biotechnology 9(30) 4802-4807.

Mohammad, A. M. and Omer M. S. 1990. " Fundamental Aspects of Plant Cell, Tissue and Organ Culture". Mosual university.

Murashige, T. and F. Skoog. 1962. A revised medium for rapid growth and bioassays with tobacco tissue cultures. Physiol. Plant. 15:473-479.

Orozco-Cárdenas, ML, Garcia D, Narváez-Vásquez, J. 2014. Tomato (Solanum lycopersicum). Methods in Molecular biology, Agrobacterium Protocols edited by Kan Wang. Third Edition Volume 2, Humana Press. Totowa, New Jersey. In press.

Rao, A. and Agarwal, S. 2000. Role of antioxidant lycopene in cancer and heart disease. J. Am. College Nutr. 19: 563-569. 
Rashid, R. and Bal, S. 2010. Effect of hormones on direct regeneration in hypocotyls explants of Tomato. Not. Sci. Biol. 2(1):70-73

Rashid, R.; Bhat. J.A.; Bhat, Z.A.; Dar, W. A. and Shafi, W. 2012. Callus formation and organogenesis of tomato (Solanum lycopersicum L.) Vegetos-An International Journal of Plant Research, 25(2):243-248.

SarwarKhan, M.; Usman, M. and Ilyas Lilla, M. 2006. Facile plant regeneration from tomato leaves induced with spectinomycin. Pak. J. Bot.,38(4):947-952.

SAS, SAS/ STAT User's Guide for Personal Computers, Release 6.12. SAS Institute Inc. Cary, NC, USA, 2001.

Soundararajan, M. 2015. Induction of organogenesis in tomato callus (Lycopersicon esculentum Mill. cv. pkm-1) using plant growth promoters including triacontanol and antioxidants. Indian Journal of Fundamental and Applied life Sciences, 5(3): 81-87.

Sutter EG.1996. General laboratory requirements, media and sterilization methods. In: Trigiano RN, Gray DJ (eds), Plant Tissue Culture Concepts and Laboratory Exercises. New York, USA: CRC Press. pp. 11-25

Wayase, U. R. and Shitole, M.G. 2014. Effect of plant growth regulators on organogenesis in Tomato (Lycopersicom esculentum Mill.) cv. Dhanashri. Int. J. Pure Appl. Sci. Technol., 20 (2):65-71. 


\section{Gharbia Danial - Diaa Ibrahim}

Doi: 10.21608/asajs.2020.67988 